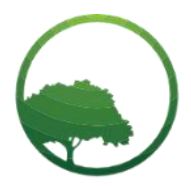

Research in Business \& Social Science

IJRBS VOL 11 NO 1 (2022) ISSN: 2147-4478

\title{
Legal protection on discrimination towards transwomen in DKI Jakarta from human rights perspective
}

\author{
(D) Kherent Obeth Sine ${ }^{(a)}$ (iD) Asmin Fransiska ${ }^{(b) *}$ \\ ${ }^{(a, b)}$ Faculty of Law, Atma Jaya Catholic University of Indonesia, Jakarta, Indonesia
}

\author{
A R T I C L E I N F O \\ Article history: \\ Received 02 January 2022 \\ Received in rev. form 02 Feb. 2022 \\ Accepted 11 February 2022 \\ Keywords: \\ Dicrimination, human rights, legal \\ protection, transwomen, violence \\ JEL Classification: \\ K10
}

\begin{abstract}
A B S T R A C T
Human rights protection must be carried out without any form of discrimination. However, this is contrary to what happened to the sexual minority group (LGBTQIA+), especially for this matter, transwomen. Transwomen are seen as something different, something bad, immoral and the negative stigma from society is attached to every individual who is part of the group. In interviews conducted with several transwomen, discrimination against their group in various forms seems to be normalized even though, both internationally and nationally, legal protection and human rights of transwomen are guaranteed in every Declaration and International Human Rights Convention ratified by Indonesia, as well as set out in instruments national human rights laws such as the 1945 Constitution, Law no. 39 of 1999, and other human rights regulations. The research intends to explore the legal protection of discrimination against sexual minority groups (transwomen) in DKI Jakarta from a human rights perspective. When all are treated equally, discrimination should not occur. As long as there are no legal provisions that specifically regulate transwomen groups, their human rights should be guaranteed as human beings who have rights and dignity over themselves. This research is using the empiric juridical method through interviews and focus group discussion with the community or participants from transwomen and sexual minorities groups in Jakarta.
\end{abstract}

(C) 2022 by the authors. Licensee SSBFNET, Istanbul, Turkey. This article is an open access article distributed under the terms and conditions of the Creative Commons Attribution (CC BY) license (http://creativecommons.org/licenses/by/4.0/).

\section{Introduction}

Humans and Human Rights are an inseparable unit. The two are interrelated since human rights are inherent in an individual from birth until the entity ceases to exist from life. Purba et al. (2020) defines human rights as rights that have been obtained and brought along with their birth and presence in people's lives. This right exists in humans without distinction of nation, race, religion, class, gender, since it is basic and universal. Another expert, Thomas Jefferson defines human rights as human freedoms which are not given by the State, but this freedom comes from God which is attached to human existence (Knoles, 1943). Thus, human rights may be defined as a basic and universal right originated from God, which is attached to an individual since birth (Hadiprayitno, 2010).

Article 28A of the Constitution of the Republic of Indonesia states that, "Every person has the right to live and has the right to defend his/her life and livelihood". Article 9 of Law Number 39 of 1999 concerning Human Rights also clearly states that every citizen has the right to defend their life and has the right to have peace, security, peace and prosperity for their life.

Law Number 39 of 1999 concerning Human Rights in Article 1 Point 3 describes discrimination as any restriction, harassment, or exclusion which is directly or indirectly based on human differences on the basis of religion, ethnicity, race, ethnicity, group, class, social status, economic status, gender, language, political beliefs, resulting in the reduction, deviation or erasure of the recognition, implementation or exercise of human rights and basic freedoms in both individual and collective livelihood in the political, economic, legal, social, cultural sectors and other life aspects. In the Convention on the Elimination of All Forms of Discrimination against

\footnotetext{
* Corresponding author.

(C) 2022 by the authors. Hosting by SSBFNET. Peer review under responsibility of Center for Strategic Studies in Business and Finance.

https://doi.org/10.20525/ijrbs.v11i1.1600
}

Citation: Sine, K. O., \& Fransiska, A. Legal protection on discrimination towards transwomen in DKI Jakarta from human rights perspective. International Journal of Research in Business and Social Science (2147-4478), 11(1). 
Women (CEDAW), Article 1 states that "discrimination against women" means any distinction, exclusion or restriction made on the basis of sex, which has the effect or purpose of reducing or erasing the awareness, consummation or exercise of human rights and basic freedoms in the political, economic, legal, social, cultural, civil or any other sectors by women, regardless of their marital status, on the basis of equality between men and women.

All forms of violence are a form of previous discriminatory behavior. Therefore, discriminatory behavior is intolerable. To achieve this, it shall not only be conducted by a few parties, but a wider community must participate in ensuring legal protection and human rights for trans women. As stated in Article 28 I paragraph (2) of the 1945 Constitution which stipulates that "Everyone has the right to be free from discriminatory treatment on any basis and is entitled to protection against such discriminatory treatment."

In fact, discriminatory behavior against minority groups is still happening. Gender-based minority groups are also vulnerable to discriminatory acts, including transgender women (Transwomen). Since ancient times, people have known the term "transgender" which is often used to describe men who behave like women, both in appearance and behavior (Grossman et al., 2006). Over time, other terms to describe the "waria" group emerged, the most frequently used being transwomen.

A transwoman is a person who acts, feels, thinks or looks different from her assigned gender at birth (Nugroho et al., 2018). Those who feel uncomfortable with the gender assigned at birth may proceed to make certain changes in themselves, from only altering their style, performing sex surgery and hormone injections, to changing their complete identities according to their new gender. A transwoman is a term for those who are transitioning their gender from male to female (Norwood, 2012).

In Indonesia, transgender groups are not a new phenomenon (Horn et al., 2009). Since 1960, the first term for transgender women appeared in Indonesia, namely "Wadam", an abbreviation for women and adam. In 1973, the first organization in Indonesia that houses a transgender group was formed called the Djakarta Wadam Association (HIWAD) (Muthmainnah, 2016). Ever since the transgender community in Indonesia has flourished. Even today, the naming and terms about sexual identity are also growing and diverse. Initially, the term used to identify a person's sexuality was limited to Lesbian, Gay, Bisexual, and Transgender (LGBT), but nowadays the term sexual identity has become diverse (Reinah, 2021) which includes Lesbian, Gay, Bisexual, Transgender, Transexual, Queer, Questioning, Intersex, Asexual, Ally, and Pansexual (hereinafter referred to as LGBTQIA+). Gender-based groups that are considered not in accordance with social norms that apply in society often get different treatment such as being ostracized, harassed, rejected from society, as well as transgender women and other transgender people who are considered immoral and violate religious rules. Back to the basic rights of an individual. In Indonesia, the basic rights regulated in the 1945 Constitution or in all other human rights instruments do not give exceptions to certain groups or to transwomen. With this, transgender women should also be taken into account all their rights and respected as human being who is part of society.

The Community Legal Aid Institute (LBH Masyarakat) conducted research throughout 2017 and there were 715 transgender people victims of sexual orientation-based discrimination and violence (Listiorini et al., 2019). During 2014-2019, the Indonesian Lentera Style Color Network (GWL-INA) recorded 24 murder cases against trans women in Indonesia. Even during the pandemic, cases where transgender women were victims of discrimination and violence kept popping up. On April 4, 2020, a 43-year-old transwoman named Mira was accused of stealing the wallet and cell phone of one of the perpetrators. Apart from being accused of stealing, Mira became a victim of abuse and murder by the perpetrators by dousing them with gasoline and burning them alive (Siburian \& Hutabarat, 2021). In the city on May 4, 2020, a YouTuber, Ferdian Paleka action prank against transwoman by providing plastic "food" but it turns out when opened, the plastic trash and rocks. In an interview uploaded on the Youtube channel "Being Human", several transwomen were invited and told that they had experienced discrimination ranging from verbal, discriminatory actions that were manifested by throwing garbage at them, being bullied or humiliated in public with their pants pointed at them, and all other unpleasant actions (Nugroho et al., 2017).

This study will use a sociological juridical method, meaning the research projects to perceive the issue existing in society related to applicable regulations (Salma et al., 2020; Maskur \& Subondo, 2017). This research is qualitative because it will focus on the depth of the data with descriptive-analytical method. The type of data that will be collected and studied in this study is primary data, namely the author will observe a little of the daily life of the research subjects before conducting interviews to explore further primary data. The technique of collecting data is snowball sampling, which is a technique of determining the sample, which is initially small in number, eventually grows. The data commence with one transwoman respondent, cotinues with three, grew to five and ends with a total of 15 respondents for the completeness of the data needed for writing. The respondents in the interest of this research are a transgender group part of the X Foundation in Jakarta, working as buskers. All respondents verbally stated that three transwomen respondents were met directly by the researcher so that the interviews were conducted face-to-face, the other 12 were conducted by distributing questionnaires due to limitations in meeting respondents during the pandemic. The whole process is carried out by consent by respondents without pressure and prioritizes research that is not re-victimizing and stigmatizing.

This violence occurred in almost all areas in Indonesia, especially in DKI Jakarta. Seeing various legal issues, especially human rights, including discrimination experienced by sexual minority groups. The main objective of this study is how the legal protection for discrimination experienced by sexual minority groups (trans women) in DKI Jakarta. 


\section{Literature Review}

Non-discrimination is one of the principles of human rights. Human rights is interrelated and inseparable from one right to another. As a natural law scholar such as Knoles (1943), he relates human rights to freedom and right from god. Furthermore, Purba et al. (2020) state that human rights began when humans were born. Human rights-based on national and international law instruments have elaborated the non-discrimination principles. Those are the Indonesian Constitution, Universal Declaration of Human Rights (UDHR), International Covenant on Civil and Political Rights (ICCPR), as well as International Covenant on Economic, Social and Cultural Rights (ICESCR). The Convention on the Elimination of All Forms of Discrimination against Women (CEDAW) in Article 1 elaborates the definition of discrimination as one of gender-based violence.

Regarding the discrimination towards transgender, there is not much literature that focuses on the discrimination against them in Indonesia. A transwoman is a part of sexual minorities groups in LGBTQIA+ (Reinah, 2021). Horn et al. (2009) state that transgender groups are not a new phenomenon in Indonesia and have formed several community groups. Despite State has an obligation on human rights as stated in Novitsky (2018) and Carozza (2003), however, several pieces of research on discrimination against transgender have been conducted, such as by The Community Legal Aid Institute (LBH Masyarakat) and in Listiorini (2019) found that the transgender people are the victims of sexual orientation-based discrimination and violence.

This research is based on several national and international human rights laws and linked them to transwomen's human rights issues in DKI Jakarta. Those issues are rights to welfare, the right to life, torture and degrading treatment, legal protection, and equality before the law. Novitsky (2018) elaborate that one of the elements required to be fulfilled is that the State must provide guarantees for human rights, and Dewi (2016) confirms that the State must also strive for respect for human rights for everyone whose human rights are violated by providing legal assistance in order to achieve a fair legal process and still uphold human rights.

Human rights abuses appear in public and private life. The transwomen in Jakarta also face the form of gender-based violence that results in physical, sexual, or psychological harm or suffering, including threats of such acts, coercion or deprivation of liberty, arbitrarily, which occurs in public or private life as written by Akhmedshina (2020). The violence against trans women begins with discriminatory practices and the lack of legal protection from the State or law enforcement officers. Human rights should be recognized by every legal subject, including the sexual minorities, and Sigilupu (2018) elaborates that human as legal subjects have the right and obligation to conduct a legal action. However, this research finds that those rights are still a challenge to obtain for trans women.

\section{Analysis on Forms of Discriminative Treatment of Transwomen}

This research was conducted in the residential area of Bintaro residents, Pesanggrahan District, South Jakarta, it was found that 15 respondents interviewed on May 25, 2021 had received discriminatory treatment from family, relatives, friends, to the general public such as residents living in the vicinity. 13 Transwomen respondents who also admitted that they had been victims of violence and abuse, most of which were carried out by local residents or the local community while doing their job, such as singing. Respondents are part of the Transwomen X Community in Jakarta. 3 respondents provided their statements through direct interviews, the other 12 by briefly answering questionnaires due to the pandemic. The discriminative behavior experienced can be seen in Figure 1 .

Discriminative Behavior Experienced by 15 Respondents

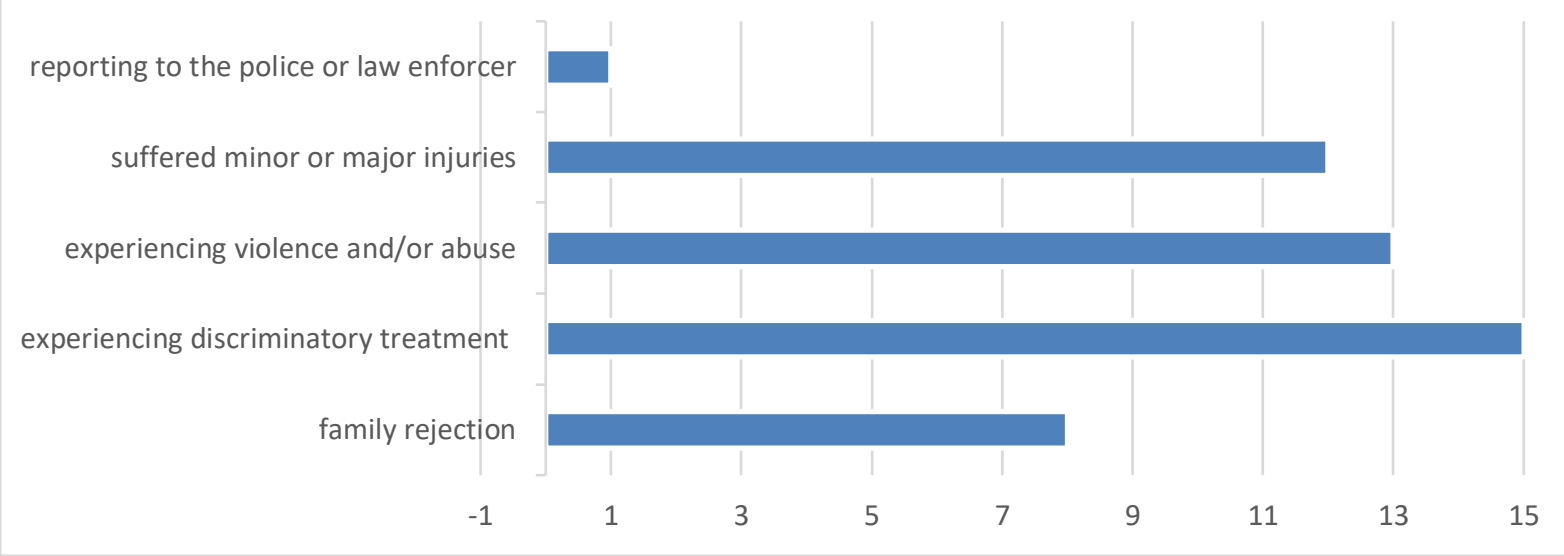

Figure 1: Discriminative Behaviors experienced by respondents 


\section{Right to Welfare}

Discrimination from the surrounding environment makes it difficult for transwomen to meet their own welfare. In fact, the right to welfare is guaranteed in Law no. 39 No. 1999, starting with Articles 36-42 which cover ownership of something, the right to work, the right to wages, the right to live and the right to social security. In particular, the right to social welfare is also regulated in Law no. 11 of 2009 concerning Social Welfare states that the implementation of social welfare is one of the priorities for victims of violence, exploitation and discrimination.

Various factors ranging from the family environment, social environment, administrative and economic interests are factors that affect the difficulty of fulfilling welfare rights for trans women. Based on the information obtained in the study, the group of transwomen who were respondents admitted that they received rejection not only from their families, but also from the surrounding community. Rejection from the family resulted in the transwoman leaving the house or being kicked out by her relatives as quoted below:

"(I) was ostracized by my own family, insulted, spat at the first time when they saw me dressed and dressed as a woman"

As a result of limited education and skills, as well as a lack of economic conditions, transwomen survive on their own by taking any job opportunities. In fact, even when transwomen decided to work, they get rejected from various job opportunities. Even if they are accepted, transwomen are forced to hide their identity and even have to be prepared to face inappropriate treatment from their coworkers or those who employ them. Therefore, there are very few job options available and accessible for trans women with minimal skills and knowledge, such as working as hairdressers in salons, commercial sex workers (PSK), masseurs, gamers, which do not provide them with a decent income to work to meet daily needs.

One of the research respondents shared her experience when she first decided to become a trans woman. Strong rejection was shown from within the family directly, the day he told his parents about his sexual orientation. The other 7 respondents also experienced the same thing. They admitted that they were not accepted by their own family as a result of their decision to become a trans woman. 5 of them decided to leave the house just as it is, not carrying their identity and personal documents, or enough money to support themselves. In job seeking, one of the challenges faced by trans women is that the lack of administrative documents such as an Identity Card (KTP) prevents trans women from registering themselves to obtain a decent job which may generate sufficient income. Therefore, the job options for transwomen who live in limitations are also limited. Most members of the Jakarta Srikandi Community work as makeup artists in salons, presenters or performers, Commercial Sex Workers (PSK), and the largest number of them are buskers.

The refusal coming from various places of work when they found out that they were trans women made it impossible for them to work conveniently. There are several workplaces that are willing to accept them on one condition, which they must completely cover up their identity as transwoman, as quoted in the interview:

"I was once accepted to work in a workshop on the condition that I had to be a man. But I am very uncomfortable, Sis, the pay is insufficient since I am a transgender, the boss also said I should be grateful that I still got a job, do not want to say much. I do not feel like a human at all. So I just left, went far away to where people did not know me to look for work so I could eat."

"When my boss found out I was a transgender, he started to speak ill, Sis. (He) insulted and say that I would infect other people. I was confused right Sis, as to how come my friend will become infected, and becomes transwoman?"

Within the course of this research, the author also had time to talk with several employees at a company Z in Jakarta related to the view of transwomen (and transgender groups in general) to work. The negative stigma that transwomen are disease is the reason for these employees to refuse their existence in their work environment.

"If here (at the company the employee and the author work) it is clear that they will not be accepted. Kan starting time will be asked gendered male or female, years later answered two-second to none. I don't want to work with them either. I'm afraid I'll pass it on to my co-workers."

Not only the difficulty of finding a job, verbal discrimination often occurs when trans women are looking for income as buskers. Words with negative connotations demeaning them as individuals have become their daily diet. The stigma arising from the assessment that LGBTQIA+ is a disease that must be cured is inherent in society, hence it is not uncommon for people to perceive that LGBTQIA+ behavior may be "contagious" to other people if left unchecked. The LGBTQIA+ community has a bad stigma that views an unusual sexual orientation as something deviant, something bad, a disease that must be cured, and also many who think that LGBTQIA+ is a mistake. Wrong in education, wrong in socialization. Moral and religious views with various interpretations and different perspectives often encourage the view that LGBTQIA+ is contradictory with the values of beliefs and social norms that exist in society.

Respondent 4 recounted that the insults they heard about themselves coming from the community had been heard so often that they had become numb and could not be offended as quoted below:

"It's not just being shouted 'bencong', Sis, we've been called by all kinds of animal names from a to z. We are always looked down upon even though we are also looking for halal money. (We) don't hurt other people, don't harm other people." 
This behavior does not only originate from the adult society, but the children also shouting degrading slurs. Respondents were shocked by their experiences, such as "being called 'the proboscis monkey', which was shouted by a child. Not to mention that trans women are also ridiculed by residents and labeled as prostitutes, even though they actually make a living from singing and busking.

\section{The Right to Life}

Article 6 of the International Covenant on Civil and Political Rights (ICCPR) states that "Every human being has the inherent right to life. This right shall be protected by law. No one shall arbitrarily be deprived of his life". The right to life is also regulated in Article 28A, 28I paragraphs (1) and (2) of the 1945 Constitution and Article 9 of Law no. 39 of 1999. This right to life is often unmet for the sexual minority groups. In addition to the difficulty in fulfilling the rights to welfare experienced by trans women, 13 of the respondents admitted that they experienced acts of violence to abuse at work. Transwomen seem to live in fear of their daily work which carries the risk of being treated as non-human. Starting from experiencing violence such as being thrown at with stones which may cause physical injury, being thrown by other objects which may harm others, to being beaten and mistreated in various forms. As a result, transwomen have the potential to be seriously injured and unable to work, even worst, may lead to death. Not to mention the transwomen at their busking work are often experienced being accused of various kinds of crimes by residents around their busking location. The majority of respondents have conveyed the same thing.

"Usually being thrown at with pebbles. It doesn't hurt if just once, but if you do it many times, it hurts. I've been hit with a shard of tiles, which are sharp, sis. I've also been hit with half of a brick, too hard that got my head bleeding."

This incident did not only happen to 1 respondent, but to 8 other respondents. Not only being hit by stones, the transwomen also admitted that they were often grazed on purpose while walking on the sidewalks which they thought were pedestrian areas. After being grazed, the transwomen were also shouted at "sissy", "bencong" and various other inappropriate slurs.

"I was ready to go home and took an angkot (city transportation) to the station. I had only stepped on one foot to get on, and the angkot was already driven off and the attendant on duty pushed me and spat at me. As a result, I fell, my back and waist were swollen."

A lot of transwomen who have also gone through similar things have experienced injuries and made them unable to sing and make money. Some of them are only minor injuries and may be taken care of by self-treatment, some of them are up to broken bones due to being hit and the perpetrators are not taking responsibility. However, from the various encounter experienced by these transwomen, she added that she is still grateful that even though she has experienced violence, she is still able to live and earn a living. One respondent told of the worst incident that ever happened to her when she was going home after busking all day, such as her bag and all of the items therein being snatched by a group of blokes. After she released her belongings, a group of 4 blokes got off their motorbikes to beat and kick the respondent until she fell to the ground.

"It was late sis, the situation just happened to be quiet. My bag was snatched, all my money and my cellphone were taken. I thought they were satisfied, yet in fact they got off the motorbike to beat me. Then I fell, already lying down, I was kicked non-stop. On the head, stomach, waist, everything was bruised. My temples were torn and bleeding, but when I wanted to ask the residents for help, I was being accused of all kinds of things. I'm afraid that things will be wronged so that I walk home from Kebayoran because all the costs for taking the train are in my bag."

"Not to mention sis, people around were odd. Later when similar things happened, such as, loss of a cellphone, or wallet, and we happened to be passing by or busking there, we could be beaten by the residents, accused of stealing. Even though we didn't do anything at all."

Trans women's right to life is often being violated and there is no responsibility from the country, in this matter the law enforcers to punish the perpetrators. One of the violations of the right to life experienced by Transwomen occurred in 2020 in Cilincing, North Jakarta, namely the killing of a Transwoman named Mira who was burned alive by a group of men accused of stealing.

The incident started when a truck driver parked his vehicle in Mira's neighborhood, lost his wallet and cellphone shortly after meeting Mira. Out of suspicion, the truck driver and residents came to her residence and searched her room, but no evidence was found. The next day a number of thugs and the truck driver came to Mira. Mira was beaten and forced to admit what she had done even though Mira was not proven to have committed theft. Finally, Mira was doused with gasoline and burned alive.

Allegations against transwomen that ended in abuse and murder did not happen only once. In 2009 in South Jakarta, a similar incident happened to a transwoman named Rico. A man loses his cell phone in the vicinity of Rico's regular hangout and suspects that it was Rico who stole it. Even though at the time of the incident, Rico was at home. When arrested and interrogated, Rico admitted that she was kicked, beaten, urinated, doused with alcoholic beverages, and burned with cigarette flames in her arm.

\section{The Right of Legal Protection and Justice}

In an effort to legal protection, the principle of the positive obligation to the country arises as consequence of all rules on human rights. The country must not intentionally ignore the rights and freedoms of individuals, though the state acts as a duty bearer which to actively protect, guarantee and fulfill the human rights of every person who in this case becomes a right bearer. As a rule of law country, one of the elements required to be fulfilled is that the state must provide guarantees for human rights (Novitsky, 2018). The 
state must also strive for respect for human rights for everyone whose human rights are violated by providing legal assistance in order to achieve a fair legal process and still uphold human rights (Dewi et al., 2016). The right to obtain legal and human rights protection is regulated in Article 28I paragraph (4) and (5) of the 1945 Constitution. Of all the treatment experienced by trans women, only a few reported it to the authorities or law enforcement for protection. There are various factors cause transwomen to choose not to report, one of which is that she deserves such treatment because she is transgender.

"I just accept that you are being treated like this, as long as I can live and sing it's fine. The important thing is that I can eat. After all, they (the community) are like that because I am a transwoman. So, it's okay."

There are also those who do not report because they feel it was useless, since they have previously reported but have not received any response from law enforcement officials.

"How could I report Sis, even to the local RT and RW, I was never considered to exist. How many times have I reported to the RT and RW when I was beaten by people on my way home asking for help, but there was no response? How do I go to the police?"

"Why should I report it, no one really cares. Better to take it by myself."

"I have tried reported (to the authorities), the community has also assisted me. But no progress. When being asked the answer is always the same, will be processed later they said. Until today, there is no continuation, Sis."

Rico admitted that when he was arrested and examined, he experienced torture such as being kicked, beaten, urinated, doused with alcoholic beverages, and burned by cigarette flames. He was forced to confess to the crime of theft. As a result of these experiences and stories, transwomen's sense of trust in law enforcement is also decreased. There are even those who completely do not trust due to the discrimination and torture that are often carried out by the police. Whereas in Article 13 of Law no. 2 of 2002 concerning the Indonesian National Police, it is stated that the main tasks of the Indonesian National Police are:

i. Maintain public security and order;

ii. Enforce the law; and

iii. Provide protection, shelter and service to the community.

In an effort to fulfill the right to protection and equality before the law, the community that houses transwomen does not remain silent. If it is found that there are acts of violence or abuse experienced by transwomen, transwomen will rely more on first aid and protection from the community since in their community they feel more valued and respected. Together, the administrators and community members advocate for transgender women who are victims of criminal acts and human rights violations, especially violence and abuse which may affect their daily livelihood.

\section{Discriminatory Practices as violence against human rights towards transwomen}

Based on Article 1 Point 3 of Law no. 39 of 1999 concerning Human Rights, discrimination is defined as:

"Every restriction, harassment or exclusion which is directly or indirectly based on human differences on the basis of religion, ethnicity, race, ethnicity, group, class, social status, economic status, gender, language, political belief, which results in a reduction, deviation or erasure of the recognition, implementation or use of human rights and basic freedoms in both individual and a collective life in the political, economic, legal, social, cultural and other aspects of life."

There are various forms of discrimination. According to Newman, the forms of discrimination may take various forms, such as verbal, physical, sexual discrimination to the distinction and limitation of equal rights. CEDAW definition discrimination as followed:

"For the purposes of the present Convention, the term 'discrimination against women' means any distinction, exclusion or restriction made on the basis of sex which has the effect or purpose to reduce or eliminate the recognition, enjoyment or use of the human rights and freedoms fundamental in the political, economic, social, cultural, civil or any other field by women, regardless of their marital status on the basis of equality between men and women."

Based on the findings in the study, the discriminatory behavior experienced by trans women in Jakarta who were the research targets were:

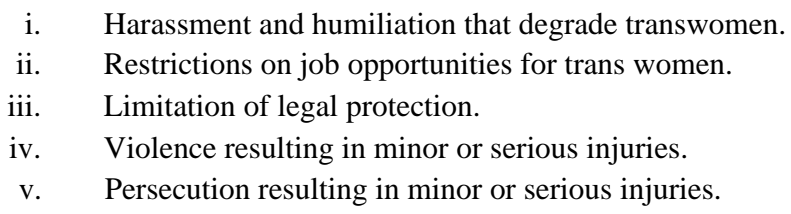

Discriminatory behavior experienced by transwomen in DKI Jakarta is a form of human rights violation that should be followed up in accordance with applicable law. Article 4 of Law no. 39 of 1999 stated that, "The right to life, the right not to be tortured, the right to freedom of personality, thought and conscience, the right to religion, the right not to be enslaved, the right to be recognized as a person and equal before the law, and the right not to be prosecuted on the basis of retroactive law is a human right that cannot be 
reduced under any circumstances and by anyone." Based on this, the state has full responsibility to protect the human rights of every citizen based on the mandate of international and national human rights law (Carozza, 2003). In addition to the 1945 Constitution and Law no. 39 of 1999 concerning Human Rights, the enforcement and fulfillment of individual human rights must also be based on international human rights instruments that have been ratified by Indonesia, namely, the Convention on the Elimination of All Forms of Discrimination Against Women (CEDAW), the Convention on the Rights of the Child, the Convention Against Torture, the Convention on the Elimination of All Forms of Racial Discrimination, Covenant on Economic, Social and Cultural Rights (ICESR), Covenant on Civil and Political Rights (ICCPR) and Convention on the Rights of Persons with Disabilities. Legal protection against discrimination against transgender women is also carried out under the Criminal Code (KUHP) and other provisions outside the Criminal Code.

One form of discrimination expressed by Newman is verbal discrimination, which is a form of discrimination that is carried out by insulting or using words (Universal Declaration on Human Rights). International and national human rights law instruments condemn all forms of discrimination against an individual as stated in Article 2 of the UDHR:

"Everyone is entitled to all the rights and freedoms set forth in this Declaration without any exceptions, such as race, color, sex, language, religion, political or other opinion, national or social origin, rights property, birth or other position."

It is echoed by article 2 (1) of ICCPR and Article 2 (2) of ICESCR

"Each State party to the present Covenant undertakes to respect and guarantee the rights recognized in the present Covenant for all persons within its territory and subject to its jurisdiction, without distinction of any kind such as race, colour, sex, language, religion, political or other's opinion, national or social origin, property, birth or other status."

"The States Parties to the present Covenant undertake to ensure that the rights set forth in the present Covenant will be enforced without any distinction as to race, color, sex, language, religion, political or other's opinion, national or social origin, possession, ancestry or other status."

Based on the above international human rights law, verbal discriminatory behavior in the form of insults with words is also prohibited and the right is protected without delay. Indonesia as one of the members of the United Nations which has also ratified the human rights instrument through the establishment of national law, should comply with and make efforts to protect the human rights of its citizens regardless of their gender identity. Therefore, transwomen who are Indonesian citizens also deserve to be respected for their rights and dignity as a human being without any verbal discrimination. The state also has the responsibility to protect transwomen from discriminatory behavior by making appropriate and necessary regulations in national legal instruments in accordance with Article 2 of CEDAW which states that, States parties condemn discrimination against women in all its forms and agree to implement by all appropriate means and without delay, the policy of eliminating discrimination against women, and to this end endeavors:

i. Include the principle of equality between men and women in their national constitutions or other appropriate legislation if it is not already included, and to ensure the practical realization of this principle, through law and other appropriate means;

ii. Making appropriate laws and regulations and other regulations including sanctions where necessary, prohibiting all discrimination against women;

iii. To enforce legal protection of women's rights on an equal basis with men and to ensure through competent national courts and other governmental bodies the effective protection of women against any act of discrimination;

iv. Not to commit any act or practice of discrimination against women, and to ensure that government officials and state institutions will act in accordance with these obligations;

v. Make appropriate regulations to eliminate discriminatory treatment against women by any person, organization or company;

vi. Make appropriate regulations, including legislation, to amend and abolish laws, regulations, customs and practices that are discriminatory against women; and

vii. Repeal all national criminal provisions that discriminate against women.”

The state's efforts to ensure protection against discrimination are stated in Article 1 of Law 39 No. 1999 concerning Human Rights which states that, "Discrimination is any restriction, harassment, or exclusion that is directly or indirectly based on human differences on the basis of religion, ethnicity, race, ethnicity, group, class, social status, economic status, gender, language", political beliefs, which result in the reduction, deviation or elimination of the recognition, implementation or use of human rights and basic freedoms in both individual and collective life in the political, economic, legal, social, cultural and other aspects of life."

\section{Torture and Degrading Treatment as Violence Against Transwomen}

Another form of discrimination experienced by transwomen is violence. This violence occurs anywhere but is often experienced when they are making a living as a busker. Starting from throwing objects that cause injuries to being beaten and kicked. Violence against women in the Declaration on the Elimination of Violence Against Women (DVAW) is defined as any form of gender-based violence that results in, or is likely to result in, physical, sexual or psychological harm or suffering to women, including threats of such acts, coercion or deprivation of liberty, arbitrarily, which occurs in public or private life (Akhmedshina, 2020). Violence that 
occurs against trans women begins with discriminatory behavior that views trans women as something that is not in accordance with the values and norms in society. This gives rise to behavior that is based on hatred towards the trans woman community and takes the form of actions that cause injury.

The risk of human rights violations for living safe from violence is something that should not be reduced or limited under any circumstances. This is stated in Article 28A of the 1945 Constitution that, "Everyone has the right to live and has the right to defend his life and life." The protection of the right to life in the 1945 Constitution is also stated in Article 28I Paragraph (1) of the 1945 Constitution which reads: "The right to life, the right not to be tortured, the right to freedom of thought and conscience, the right to religion, the right not to be enslaved, the right to be recognized as a person before the law, and the right not to be prosecuted on the basis of retroactive law is a human right that cannot be reduced under any circumstances."

The right to life is also stated in Article 9 of Law no. 39 of 1999, that "(1) Every person has the right to life, maintain life and improve their standard of living. (2) Everyone has the right to be peaceful, safe, peaceful, happy, physically and mentally prosperous. (3) Everyone has the right to a good and healthy environment."

Violence is also recognized as a crime. Article 170 of the Criminal Code states that, "Whoever openly and with joint force uses violence against people or goods, is threatened with a maximum imprisonment of five years and six months." From the case of Mira's assault, the suspect who was arrested and processed in accordance with the applicable law was charged with Article 170 of the Criminal Code. From the provisions that guarantee the right to life of citizens as individuals, women's rights to their lives should also be protected by these provisions. Acts of violence against women should be carried out by legal processes in accordance with applicable regulations in an effort to fulfill human rights which are the obligations of the state.

Cases of mistreatment and torture of trans women in the research findings occurred several times, one of which ended in death. Torture is not defined in writing in the law so that according to jurisprudence, a mistreatment is an act that intentionally causes feelings of discomfort (suffering), pain, or injury. Torture is a non-derogable right, meaning it cannot be limited or reduced under any circumstances and by anyone. Torture is defined in the CAT as “... means any act by which severe pain or suffering, whether physical or mental, is intentionally inflicted on a person for such purposes as obtaining from him or third person information or a confession, punishing him for an act he or a third person has committed or is suspected of having committed, or intimidating or coercing him or a third person, or for any reason based on discrimination of any kind, when such pain or suffering is inflicted by or at the instigation of or with the consent or acquiescence of a public official or other person acting in an official capacity. It does not include pain or suffering arising only from, inherent in or incidental to lawful sanctions" (Convention against Torture and Other Cruel). It is very unfortunate, due to the nonexistence of definition in the Indonesian Penal Code, making torture cases not protected, even relieved by including them in the category of mistreatment.

The right to freedom from torture is closely related to Article 6 of the ICCPR regarding the right to life which states that, "Every human being has the right to life which is inherent in him. This right must be protected by law. No one can be deprived of his right to life arbitrarily." The right to life is also regulated in Article 9 of Law no. 39 of 1999 which states, "(1) Everyone has the right to live, maintain life and improve their standard of living. (2) Everyone has the right to be peaceful, safe, peaceful, happy, physically and mentally prosperous. (3) Everyone has the right to a good and healthy environment."

In the Criminal Code, the definition of physical violence is attached to the persecution of whoever the perpetrator is. Articles 351 to 355 of the Criminal Code are not only seen from the consequences of persecution which can cause minor injuries, serious injuries or cause the loss of other people's lives but from their actions (Tompodung, 2021). Minor mistreatment in the Criminal Code is regulated in Article 352 of the Criminal Code which reads as follows: "Other than stipulated in Articles 353 and 356, mistreatment that does not cause illness or obstacle to carry out a position or work, is punished as light maltreatment with a maximum prison sentence. three months or a maximum fine of three hundred rupiahs. The punishment may be increased by one third for the person who commits the crime against the person who works for him or who is under his orders."

Article 351 of the Criminal Code which according to R. Soesilo is included in the definition of mistreatment is "deliberately damaging people's health". Where this "damaging to health" is defined by R. Soesilo as "damaging to health" for example, when a person is sleeping and sweating, the window of his room is opened, so that the person catches a cold (Rimporok, 2021). Thus the element of light persecution gravitates towards the consequences of the act. Serious mistreatment by law is formulated in article 354 of the Criminal Code, that: (1) "Whoever intentionally seriously injures another person, shall be punished for committing serious maltreatment with a maximum imprisonment of 8 years; (2) If the act results in death, the guilty person shall be punished with a maximum imprisonment of 10 years."

The act of severe mistreatment is an abstract formulation of actions, meaning a formulation of actions that are not clearly defined in what form, thus the form of the action consists of many concrete actions that may be acknowledged after its realization. Where the act of mistreatment resulted in death not being a factor or condition for the occurrence of severe mistreatment yet becoming a criminal aggravating factor because of severe persecution (Mills et al., 2002).

From the cases experienced by transwomen respondents, the forms of abuse experienced were mostly in the form of beatings with or without tools, beatings, beatings, until being accidentally hit with a motor vehicle. The consequences ranged from minor injuries, broken bones that made transwomen unable to earn a living, other serious physical injuries to death like what happened to Mira. 
One of the beating cases experienced by the respondent may be classified as a criminal act of severe maltreatment. The beating incident by a group of blokes after stealing the respondent's bag. The beatings done repeatedly to the head resulting in bruises to lacerations on the temples of the head and face were a form of serious injury due to the beatings. As a result, the respondent was unable to earn a living and support himself for some amount of time due to his injuries.

Violence is also punishable by imprisonment. So that if the actions taken by the community towards transwomen receive the same attention. Efforts to protect human rights for the right to life and to be free from torture for every transwoman must be carried out since all of them are guaranteed by law. The existing provisions are an effort to protect individual human rights therefore should be carried out in accordance with what prevails.

\section{The Legal Protection on the Right to Work Towards Transwomen}

From the respondents' various statements indicate that not all trans women have the opportunity to get a decent job and income such as other individuals due to the bad stigma which views an unusual sexual orientation as something deviant, something bad, a disease that must be cured. Many people also think that LGBTQIA+ is a mistake, hence the rejection in society of the existence of trans women affects their right to pursue a job and maintain their life.

Article 1 Paragraph (1) of the ICESCR states that, "All citizens have the right to determine their own destiny. This right gives them the freedom to determine their political status and to achieve economic, social and cultural progress." The right to work for transwomen is protected and recognized in other international and national human rights legal instruments as stated in Article 6 Paragraph (1) and 7 of ICESCR

"The Country Members to the present Covenant recognize the right to work, including the right of everyone to the opportunity to earn a living through work which he freely chooses or accepts and will take appropriate steps to protect this right."

"The Country Members to the present Covenant recognize the right of everyone to just and favorable conditions of work, and ensure in particular:

i. $\quad$ Benefits that provide to all workers, at least with:

ii. Fair wages and equal remuneration for work of equal value without distinction of any kind, in particular for women guaranteed working conditions not lower than those enjoyed by men with equal pay for the same work.

iii. A decent life for them and their families in accordance with the provisions of the present Covenant."

In the provisions of national law, the protection of the right to work for transwomen is stated in Article 28D Paragraph (2) of the Constitution of the Republic of Indonesia which states, "Everyone has the right to work and receive fair and proper remuneration and treatment in an employment relationship." In addition, the right to work in Article 38 of Law no. 39 of 1999 concerning Human Rights, that:

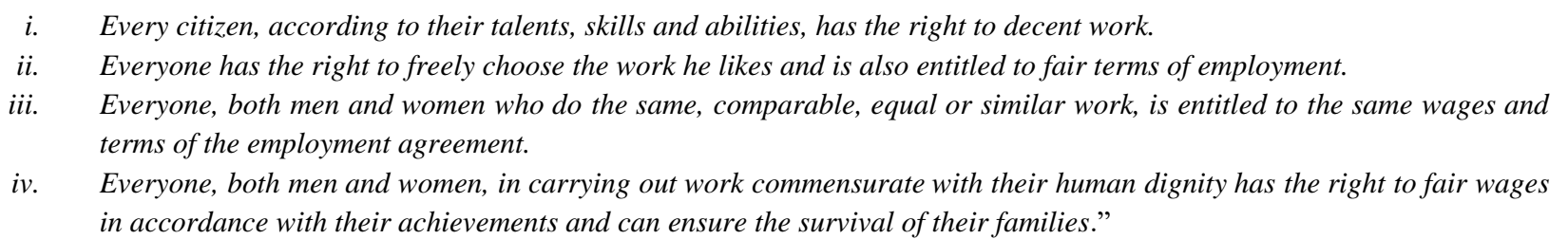
In particular, the guarantee of the right to work for transwomen is regulated in Article 5 of Law no. 13 of 2003 concerning Manpower that, "Every worker has the same opportunity without discrimination to be employed." Article 6 of the Manpower Law also states that, "Every worker/labor has the right to receive equal treatment without discrimination from employers."

The right to work for transgender women is recognized and protected by the stated provisions and must be exercised without discrimination on the basis of gender or gender identity. The fulfillment of the provision of equal opportunities for trans women should be carried out by viewing trans women as individuals, as humans and citizens. Even the remuneration for his work is also specifically regulated in Article 88 - Article 98 of Law no. 13 of 2003 concerning Manpower. Unfortunately, this law has not been implemented properly, because the discrimination that occurs against transgender women lacks protection and monitoring. In fact, omission often occurs because of this discrimination.

\section{The Protection of Equality Before the Law towards Transwomen}

The legal protection is an effort to protect a person's interests by using the power to act according to his interests. As we can say that legal protection is carried out using legal mechanisms aimed to protect dignity and worth, as well as the recognition of human rights possessed by every legal subject, since humans as legal subjects have the right and obligation to conduct a legal action (Sigilupu, 2018).

Article 28D Paragraph (1) of the 1945 Constitution states that, "Every person has the right to recognition, guarantees, protection and fair legal certainty and equal treatment before the law." Transwomen as human beings and citizens must also be recognized for their position in the eyes of the law. With the existence of legal provisions that uphold the rights and dignity of individuals to equality 
before the law, human rights violations against women should have been resolved. Transwomen should not be treated differently and inappropriately or discriminated against by law enforcers since their rights are protected in international and national human rights instruments. Article 10 of the ICCPR states that, "Every person who is deprived of his liberty shall be treated humanely and with respect for the inherent dignity of the human person." This translates that everyone, including transwomen, must be treated properly regardless of the gender identity attached to each transwoman. If legal action is taken for the alleged act against them, the principle of Presumption of Innocense is mandatory. This provision is in accordance with Article 14 paragraph (2) of the ICCPR which states, "Every person accused of a crime has the right to be presumed innocent until his guilt is proven according to law." The principle of the Presumption of Innocence is also stated in Article 16 of the ICCPR that, "Every person accused of a crime has the right to be presumed innocent until his guilt is proven according to law." That way, if a trans woman is suspected of committing a crime, the legal proceeding carried out must be in line with this principle where she must be considered innocent until it is proven that she has committed a crime and is decided in court. it is clear that legal protection in cases of torture is not protected and this violates a fundamental human right, namely torture.

Based on the research findings, transwomen admitted that they received different legal protection treatment because of their gender identity, hence trans women felt powerless to demand justice for all the unpleasant actions they received in their daily lives. Although, the degrading treatment they experience is not only prohibited by law but is a crime that has criminal sanctions. Equal treatment before the law is protected in Article 26 of the ICCPR and Article 17 of Law no. 39 of 1999 which states that:

"All persons are equal before the law and are entitled to equal protection of the law without any discrimination. In this regard the law shall prohibit any discrimination, and ensure equal and effective protection for all against discrimination on any grounds such as race, colour, sex, language, religion, political or other opinion, national or social origin, property, birth or other status."

In addition to the ICCPR which recognizes the right to protection and guarantees equal legal treatment for trans women, in Law no. 39 of 1999 concerning Human Rights, there are also legal protections for trans women as human beings, namely in Article 3 which states "Everyone has the right to recognition, guarantees, protection and fair legal treatment as well as legal certainty and equal treatment before the law." Article 5 states the same thing that (1) "Everyone is recognized as an individual human being who has the right to demand and receive the same treatment and protection in accordance with his human dignity before the law; (2) Everyone has the right to fair assistance and protection from an objective and impartial court; (3) Everyone belonging to a vulnerable group of people has the right to get more treatment and protection with regard to their specificity."

The principle of Presumption of Innocense is also recognized in national law, that in Article 18 Paragraph (1) of Law 39 of 1999 concerning Human Rights it is stated "Everyone who is arrested, detained, and prosecuted since being suspected of committing a criminal act has the right to be considered innocent, until his guilt is proven by law in a court session and given all the legal guarantees necessary for his defense, in accordance with the provisions of the laws." That way, trans women also deserve to receive fair legal services and in accordance with what is specified in the law. In an effort to fulfill the right to equality before the law, international and national human rights instruments clearly stipulate that every individual has the right to legal justice without any discriminatory behavior from any party, especially law enforcement officers and law enforcers themselves.

\section{Conclusion}

Legal protection for discriminatory behavior experienced by transwomen has not been implemented optimally. In fact, all provisions made to guarantee the human rights of transwomen are regulated in various international and national human rights law instruments. The negative stigma attached to the transwomen group results in the vulnerability of transwomen to verbal discrimination in carrying out their daily lives. All forms of insults and slurs from local residents who demean transwomen as human beings may be captured almost every time transwomen carry out their jobs.

Freedom from discrimination that demeans an individual is protected in Article 2 of the UDHR, Article 2 Paragraph (1) ICCPR, Article 2 Paragraph (2) ICESR, Article 1 and Article 2 of CEDAW, as well as Article 1 of Law no. 39 of 1999 concerning Human Rights. Violations of the rights of social welfare experienced by women are one of the results of discrimination that continues to be tolerated in society. Women with limited expertise and knowledge do not seem to be given the opportunity to choose decent jobs that can provide decent wages. The refusal and all unpleasant acts experienced by trans women in seeking work violate international and national human rights provisions that guarantee and protect the rights of trans women to have a decent life, namely, Article 1 Paragraph (1), Article 6 Paragraph (1), Article 7 ICESR, Article 28D Paragraph (2) of the Constitution of the Republic of Indonesia, Article 36 - Article 42 of Law no. 39 of 1999 concerning Human Rights, Article 5 and Article 6 of Law no. 13 of 2003 concerning Manpower, Law 11 of 2009 concerning Social Welfare.

As citizens, transwomen are also entitled to equal treatment before the law regardless of its form. However, in reality, the fulfillment of the right to legal protection has not occurred in most trans women groups. Discriminatory treatment comes from law enforcers who should be obliged to protect their people. The forms of legal discrimination experienced by transgender women include not receiving proper handling of legal cases, not realizing legal protection for criminal acts of violence or mistreatment that occur to trans women, law enforcement against transwomen is not carried out on the principle of presumption of innocence and in the process transwomen even suffer torture and humiliation. This fact contradicts with Article 28D Paragraph (1) of the 1945 Constitution, Article 
10, Article 14 Paragraph (2), the Convention against Torture, Article 16 and Article 26 of the ICCPR, Article 3, Article 5, Article 17, and Article 18 Paragraph (1) UU no. 39 of 1999 concerning Human Rights.

The right to life for trans women, which is a non-derogable right, is also violated by the community when transwomen carry out their work. Transwomen were pelted with objects that could injure themselves lightly or severely, intentionally hit by a motorized vehicle, beaten, abused, burned alive which resulted in the transgender being unable to earn a living due to her injuries and even leading to death. This incident is clear evidence that unresolved discrimination will lead to human rights violations. This violates international and national human rights provisions as regulated in Article 6 of the ICCPR, Article 28A, Article 28I paragraphs (1) and (2) of the 1945 Constitution, Article 9 of Law no. 39 of 1999, Article 170, Article 351 - Article 355 of the Criminal Code with criminal threats for violations that occur.

The state and every citizen in it must respect the human rights of every transwoman regardless of gender identity and sexual orientation. The state as a member of the United Nations in an effort to respect the human rights of transwomen must also abolish and prevent the establishment of all provisions that discriminate against and violence against transwomen and sexual minority communities with any sexual identity.

Author Contributions: Conceptualization, KOS., AF.; Methodology, KOS., AF.; Data Collection, KOS., AF.; Formal Analysis, KOS., AF.; Writing — Original Draft Preparation, KOS., AF.; Writing—Review And Editing, KOS., AF.; All authors have read and agreed to the published the final version of the manuscript.

Institutional Review Board Statement: Ethical review and approval were waived for this study, due to that the research does not deal with vulnerable groups or sensitive issues.

Data Availability Statement: The data presented in this study are available on request from the corresponding author. The data are not publicly available due to privacy.

Conflicts of Interest: The authors declare no conflict of interest.

\section{References}

Article 5 Paragraph (2) letter g of Law no. 11 of 2009 concerning Social Welfare

Akhmedshina, F. (2020). Violence against women: a form of discrimination and human rights violations. Mental Enlightenment Scientific-Methodological Journal, 2020(1), 13-23.

Carozza, P. G. (2003). Subsidiarity as a structural principle of international human rights law. American Journal of International Law, 97(1), 38-79.

Dewi, Y. T. N., Tjandra, W. R., \& Niemann, G. R. (2016). Independence of Judicial Power as a Foundation of Human Rights Judicial Function in Indonesia. International Journal of Social Science and Humanity, 6(3), 239-242.

Grossman, A. H., D'augelli, A. R., \& Salter, N. P. (2006). Male-to-female transgender youth: Gender expression milestones, gender atypicality, victimization, and parents' responses. Journal of GLBT Family Studies, 2(1), 71-92.

Hadiprayitno, I. I. (2010). Defensive enforcement: Human rights in Indonesia. Human rights review, 11(3), 373-399.

Horn, S. S., Kosciw, J. G., \& Russell, S. T. (2009). Special issue introduction: New research on lesbian, gay, bisexual, and transgender youth: Studying lives in context. Journal of Youth and Adolescence, 38(7), 863-866.

Knoles, G. H. (1943). The religious ideas of Thomas Jefferson. The Mississippi Valley Historical Review, 30(2), 187-204.

Listiorini, D., Asteria, D., \& Sarwono, B. (2019). Moral panics on lgbt issues: evidence from indonesian tv programme. Jurnal Studi Komunikasi, 3(3), 355-371.

Mills, J. F., Kroner, D. G., \& Forth, A. E. (2002). Measures of Criminal Attitudes and Associates (MCAA) development, factor structure, reliability, and validity. Assessment, 9(3), 240-253.

Maskur, M. A., \& Subondo, H. (2017). Sociological Juridical Analysis on Islamic Boarding School as an Educational Institution for Children Committing Criminal Act in Indonesia. International Journal of Business, Economics and Law, 12(4), 12-15.

Muthmainnah, Y. (2016). LGBT human rights in Indonesian policies. Indonesian Feminist Journal, 4(1), 13-29.

Norwood, K. (2012). Transitioning meanings? Family members' communicative struggles surrounding transgender identity. Journal of Family Communication, 12(1), 75-92.

Novitsky, V. V. (2018). The Guarantees of Human Rights and Freedoms in the European Union: the Experience for Ukraine. Journal of Advanced Research in Law and Economics (JARLE), 9(37), 2397-2402.

Nugroho, A., Erasmus, V., Zomer, T. P., Wu, Q., \& Richardus, J. H. (2017). Behavioral interventions to reduce HIV risk behavior for MSM and transwomen in Southeast Asia: a systematic review. AIDS care, 29(1), 98-104.

Nugroho, A., Erasmus, V., Coulter, R. W., Koirala, S., Nampaisan, O., Pamungkas, W., \& Richardus, J. H. (2018). Driving factors of retention in care among HIV-positive MSM and transwomen in Indonesia: A cross-sectional study. PloS one, 13(1), e0191255.

Purba, N., Tanjung, A. M., Pramono, R., \& Purwanto, A. (2020). Death Penalty and Human Rights in Indonesia. International Journal of Criminology and Sociology, 9, 1356-1362.

Rimporok, R. C. (2021). Jurısdıctıon Overvıew The Crımınal Actıon of Massage That Resultıng in Death Accordıng to Artıcle 351 Section (3) of The Crimınal Law Book. Lex Crimen, 10(9), 1-10.

Reinah, J. (2021). LGBTQIA+ Public Accommodation Cases: The Battle between Religious Freedom and Civil Rights. Fordham L. Rev., 90, 261. 
Salma, I. I., Suharto, R. B., \& Widayati, W. (2020). Sociological Juridical Review Of Children Appointment Through The Determination Of Judges In The Religion Court Of Semarang. Jurnal Daulat Hukum, 3(1), 9-14.

Siburian, H. K., \& Hutabarat, S. A. (2021). Positive Legal Review and Social Construction of Transwomen/Transvestites Case Analysis in Medan. Legal Brief, 10(2), 341-349.

Sigilupu, F. F. (2018). Legal Protection Mechanısm Agaınst Women Violence Human Rights Perspective. Lex Privatum, 6(4), 1-12. Tompodung, H. R. (2021). Juridical Study of the Crimınal Action of Death. Lex Crimen, 10(4), 1-12.

Publisher's Note: SSBFNET stays neutral with regard to jurisdictional claims in published maps and institutional affiliations.

\section{(a) (1)}

(c) 2022 by the authors. Licensee SSBFNET, Istanbul, Turkey. This article is an open access article distributed under the terms and conditions of the Creative Commons Attribution (CC BY) license (http://creativecommons.org/licenses/by/4.0/).

International Journal of Research in Business and Social Science (2147-4478) by SSBFNET is licensed under a Creative Commons Attribution 4.0 International License. 